Perkembangan Komunitas Arab di Indonesia: Studi Kasus Perkampungan Masyarakat Arab di Pekojan Jakarta Barat Pada Tahun 1950-2018 | Rizal Nasser, Sulasman

\title{
Perkembangan Komunitas Arab di Indonesia: Studi Kasus Perkampungan Masyarakat Arab di Pekojan Jakarta Barat Pada Tahun 1950-2018
}

\author{
Rizal Nasser, Sulasman \\ Fakultas Adab dan Humaniora \\ Universitas Islam Negeri Sunan Gunung Djati Bandung
}

\begin{abstract}
Pekojan village is one of the urban villages that has a historical role in the development of the Arab community in the city of Jakarta. Part of the Arabs living in the Pekojan village have developed rapidly, especially in trading, preaching, education and marriage. This activity has an impact on social relations between Arabs and the Indigenous population. With very close social relations activities, the Arabs were well received by the Indigenous population. However, most of the Arabs living in the Pekojan village moved to around Jakarta. The purpose of this research is to identify Arab communities spread across Indonesia and to know the development of Arab society in the form of social relations and activities in the Pekojan village, Jakarta. The method used in research is a qualitative method, namely by collecting data through literature and documentation. Data analysis techniques with heuristic methods, criticism, interpretation and historiography. The results of the study that in the 18th century the migration of Arabs had a considerable impact on the development of the Arab community in Indonesia, especially on the island of Java. In the 19 th century the wijeknstelsel policy had an impact on Arabs who came from Hadarmaut to occupy Pekojan village as a village inhabited by Arabs, such as in Pekojan village, Jakarta. In the 20th century, the Pekojan village began to be very different, some Arabs moved to around Jakarta some still settled and also built social relations and activities with the Indigenous population.
\end{abstract}

Keyword: Arabs, Community, Pekojan Village, Sosial relation. 
Perkembangan Komunitas Arab di Indonesia: Studi Kasus Perkampungan Masyarakat Arab di Pekojan Jakarta Barat Pada Tahun 1950-2018 | Rizal Nasser, Sulasman

\section{Pendahuluan}

Orang-orang Arab telah menjalin hubungan dengan penduduk Pribumi di Nusantara melalui proses perdagangan. Mereka sudah cukup lama memiliki hubungan dengan wilayah-wilayah di Nusantara yang terjalin erat kaitannya melalui proses perdagangan yang menjadi salah satu bagian terpenting dalam penyebaran Islam di Nusantara. Menurut Van Den Breg dalam bukunya yang berjudul Orang-orang Arab di Nusantara dijelaskan bahwa beberapa dari mereka datang dari Maskat, ditepian Teluk Persia, Hijaz, Mesir maupun Bagian Timur Afrika. Orang-orang Arab yang datang ke Nusantara untuk berdagang hanya sedikit dari mereka yang menetap tetapi bila mereka menetap, mereka langusng bergabung dengan para pedagang Arab yang berasal dari Hadramaut. Selain itu, sebagian dari mereka ialah para pengembara atau petualang dengan jangka waktu yang singkat untuk bisa menetap dan pergih lagi kewilayah lain di sekitar Nusantara untuk berdagang. Disamping itu, memungkin terjadi perkembangan orang-orang Arab yang mulai menetap dan tidak menetap dengan jumlah yang cukup besar, dari setiap tahunnya terdapat sekitar 30 orang yang tiba di Singapura dan dari sana kebanyakan dari mereka pegih ke pedalaman Malaka dan negeri-negeri vassal Pemerintah Hindia Belanda. Sedangkan terjadi juga di Nusantara yang sudah dikuasai langsung oleh administrasi Belanda dengan membuat kebijakan bagi orang-orang asing yang tidak memiliki sarana kehidupan atau profesi akan di tolak masuk. Beberapa diantaranya berasal dari Mekkah, yang sebagian dari masyarakatnya dari kalangan bawah dan kedatangannya hanya bertjuan mencari sumbangan dengan segala cara atau keadatangannya berkaitan ibadah haji. ${ }^{1}$

Apabila dikaitkan dengan kedatangan orang-orang Arab ke Nusantara, mereka sudah menyebarkan Islam beberapa Abad sebelumnya. Menurut Hamka bahwa orang-orang Arab sudah datang ke Nusantara pada Abad ke-7 $\mathrm{M}$ dengan ditemukannya pencatat sejarah dari Tiongkok yang mengembara pada tahun $674 \mathrm{M}$ di pesisir Barat pulau Sumatra yang mendapati satu kelompok bangsa Arab yang membuat kampung di pesisir pantai. Orangorang Arab melakukan perkawinan dengan wanita lokal, sehingga membentuk komunitas muslim yang terdiri dari orang-orang Arab pendatang dan penduduk lokal. Mereka melakukan kegiatan-kegiatan penyebaran Islam

\footnotetext{
${ }^{1}$ Lodewijk Willem Christiaan van den Berg, Hadramaut Dan Koloni Arab Di Nusantara (Jakarta: INIS, 1989), 1.
} 
Perkembangan Komunitas Arab di Indonesia: Studi Kasus Perkampungan Masyarakat Arab di Pekojan Jakarta Barat Pada Tahun 1950-2018 | Rizal Nasser, Sulasman

dan bukanlah ekspedisi resmi dari Khalifah (Raja) di Damaskus atau Baghdad serta bukan orang-orang yang membawa senjata melainkan hanya ingin berniaga dan berdagang. ${ }^{2}$

Orang-orang Arab yang ingin memasuki wilayah-wilayah di Nusantara untuk berdagang secara langsung ditangani oleh para administrasi di bawah kekuasaan Belanda. Mereka sering menyebut dirinya sebagai pendagang keliling yang membawa dagangan seperti obat-obatan, sari mawar, permata, kurma, tasbih dan kitab-kitab. Orang-orang Arab menyebar keseluruh wilayah Nusantara untuk berdagang dan menyebarkan Islam kependuduk lokal. Maka dari itu, wilayah pesisir menjadi sentra dari perdagangan dan berkembang kota-kota perdagangan yang cukup pesat. Bahkan terkenal sebagai kota-kota pelabuhan internasional dan sebagai jaringan perdagangan di dunia.

Perkembangan orang-orang Arab yang cukup pesat melalui perdagangan memungkinkan kedatangan mereka dapat memperoleh keterangan dari orang-orang yang tinggal di daerah tersebut ataupun mereka memiliki jiwa berpetualang dan berdagang. Melalui rute perdagangan tersebut, banyak keuntungan bagi pendagang Islam termasuk didalamnya para pendagang Arab yang membuat tumbuhnya kemakmuran di pelabuhan-pelabuhan penghubungan di Nusantara dari negara Teluk Persia dan Laut Merah. ${ }^{3}$

Pada abad ke-19, penelitian tentang masyarakat Arab di Nusatara telah dilakukan oleh orientalis yang bernama Van Den Breg. Beliau membuktikan bahwa sudah lama para pendagang Arab bermukim di wilayah-wilayah di Nusantara terutama di Batavia sejak abad ke-17 M, sementara orang-orang yang berasal dari Hadramaut secara massal datang ke Nusanatara pada tahun-tahun terakhir sekitar pada abad ke-18, mereka mulai menetap dan menghuni beberapa wilayah di pulau Jawa pada tahun $1859 .{ }^{4}$

Kedatangan orang-orang Arab dari Hadramaut secara massal terjadi sejak Terusan Suez dibuka pada tahun 1869. Dari terbukanya Terusan Suez memperlancar orang-orang Arab dalam berdagang dan berlayar yang menghubungkan antara Asia dengan Eropa. Begitu juga terbukannya Terusan Suez memberikan dampak yang baik bagi pemerintahan Kolonial

\footnotetext{
${ }^{2}$ Hamka, Dari Pembendaharaan Lama (Jakarta: Gena Insani, 2017), 3-4.

${ }^{3}$ Hamid Agadri, Islam Dan Keturunan Arab Dalam Pemberontakan Melawan Belanda (Bandung: Mizan, 1996), 80.

${ }^{4}$ Van Den Breg, Orang Arab Di Nusantara (Depok: Komunitas Bambu, 2010), 95 100.
} 
Perkembangan Komunitas Arab di Indonesia: Studi Kasus Perkampungan Masyarakat Arab di Pekojan Jakarta Barat Pada Tahun 1950-2018 | Rizal Nasser, Sulasman

yang cukup banyak melakukan impor mesin dan perlengkapanperlengakapan modern untuk meningkatkan produksi industri perkebunan dan pabrik gula. Perluasan produksi tanaman ekspor dan impor barangbarang dari Eropa mengakibatkan perdagangan International semakin ramai dan berdampak juga pada pelabuhan-pelabuhan di Nusantara. ${ }^{5}$

Orang-orang Arab yang berasal dari Hadramaut memiliki motivasi besar dari segi ekonomi. Beberapa alasan orang Arab datang ke Nusantara yaitu mencari penghiduan yang lebih layak dari negeri asal mereka, mereka menjalin hubungan perniagaan dan perdagangan serta memiliki misi besar orang-orang Arab dalam menyebarkan Islam ke wilayah-wilayah di Nusantara dengan melalui pelabuhan-pelabuhan besar. Kehidupan orangorang Arab cukup sederhana, bahkan mereka tidak menyukai hidup hedonis dan berkemewah-mewahan seperti pendatang yang berasal dari Eropa yang selalu menghabiskan pendapatannya. Selain itu, orang-orang Arab lebih memiliki sifat untuk menabung dan saling membantu sesama muslim dengan memberikan sumbangan-sumbangan untuk membangun masjid serta membangun sarana-sarana Pendidikan Islam.

Orang-orang Arab sudah menjalin hubungan sosial dengan penduduk Lokal. Bahkan pengaruh dari berdagang memberikan dampak yang cukup besar dari munculnya berdakwah, pernikahan dan pendidikan. Selain itu, mereka membentuk sebuah masyarakat yang nampaknya hanya orang-orang Arab. Dalam kaitannya dengan masyarakat yaitu sebuah perpaduan antara heterodenis dengan keteraturan, bahwa manusia memiliki bentuk modern dari perdaban manusia, awalnya dari bentuk komunitas yang berkembang menjadi suatu kelompok dan akhirnya membentuk sebuah masyarakat yang menghuni daerah tersebut. Masyarakat terdapat dari individu-individu manusia yang tergabung dalam organisasi yang dapat dikemukkan menjadi masyarakat sebagai manusia-organisasi. ${ }^{6}$

Dalam hubungan sosial antara masyarakat Arab dengan penduduk lokal menghasilkan suatu pola yang saling mempengaruhi, sehingga dapat terciptanya kekeluargaan, kebiasaan dan kebudayaan baru yang salin di

\footnotetext{
${ }^{5}$ Marwati Djoened Poesponegoro dan Nugroho Notosusanto, Sejarah Nasional Indonesia IV (Jakarta: Balai Pustaka, 1993), 122.

${ }^{6}$ R.Nugroho dan G. Sumodiningrat, Membangun Indonesia Emas (Jakarta: Elex Media Komputindo, 2005), 112.
} 
Perkembangan Komunitas Arab di Indonesia: Studi Kasus Perkampungan Masyarakat Arab di Pekojan Jakarta Barat Pada Tahun 1950-2018 | Rizal Nasser, Sulasman

adopsi antar kedua belah pihak. ${ }^{7}$ Dengan hubungan sosial tentu memunculkan interaksi yang dimiliki masyarakat Arab terhadap penduduk lokal yang menempati wilayah Nusantara dapat diakatan menjadi sebuah persaudaran dari siklus perdagangan dan perniagaan.

Masyarakat Arab cukup banyak yang tinggal dan menetap di Nusantara. Orang-orang Arab menetap di kampung-kampung yang diberikan dari sebuah dampak terhadap kebijakan yang dikeluarkan oleh pemerintahan Kolonial Belanda. Kebijakan wijkenstelsel memberikan aturan yang menciptakan pemukiman orang-orang Arab di sejumlah kota pada masa Hindia Belanda. Mereka tidak diperbolehkan untuk tinggal disembarang tempat pada masa tersebut. Dengan begitu, orang-orang Arab tidak bisa melakukan perjalanan jauh tanpa ada surat jalan dari pemerintah Kolonial. Orang-orang Arab yang bermukim di kampung tersebut dinamakan sebuah kampung Pekojan. Hingga saat ini, kampung Pekojan menjadi kampung yang dihuni oleh orang-orang yang berketurunan Arab.

Kebanyakan orang-orang Arab dari Hadramaut di Indonesia yang tinggal di kampung Pekojan memiliki hubungan keturunan dengan nenek moyang yang berhasil sampai ke negeri tersebut. Istilah 'nenek moyang' tidak dipilih secara sembarangan. Pertama, sebagian besar orang-orang Arab Hadramaut yang bermigrasi adalah laki-laki bujangan atau laki-laki yang meninggalkan keluarga mereka di Hadramaut dan menikah dengan penduduk setempat di negara tuan rumah mereka. Kedua, kesamaan dengan sebagian besar masyarakat Timur Tengah, silsilah terutama dilacak melalui laki-laki. Oleh karena itu, keturunan seorang pria Hadramaut dan seorang wanita lokal Indonesia dapat diangga sebagai Hadrami. Di Indonesia, dengan komunitas Arab yang cukup besar dan organisasi-organisasi Arab Hadramaut yang sangat berkembang, identifikasi yang dapat dilihat dengan masyarakat di tuan rumah sebenarnya sudah biasa di Hadramaut selama beberapa abad terakhir, berbeda dengan masyarakat Hadramaut yang tersebar di wilayah Hydrabad, India dan Sudan. ${ }^{8}$

Eksistensi keberadaan masyarakat Arab di Indonesia telah membentuk komunitas Arab-Hadrami dari peranakan Arab Yaman mulai bermukim dan menempati wilayah-wilayah di Jawa terutama di Jakarta. Di Jakarta terdapat

70.

${ }^{7}$ Koentjaraningrat, Penghantar Ilmu Antroologi (Jakarta: Aksara Baru, 1980), 267 2009), 20.

${ }^{8}$ Frode F.Jacobsen, Hadrami Arab In Present-Day Indonesia (London: Routledge, 
Perkembangan Komunitas Arab di Indonesia: Studi Kasus Perkampungan Masyarakat Arab di Pekojan Jakarta Barat Pada Tahun 1950-2018 | Rizal Nasser, Sulasman

sebuah kampung Arab yaitu Kampung Pekojan. Masyarakat Arab bermukim di kampung Pekojan yang selalu menghadirkan nuansa-nuansa keAraban dalam bentuk hubungan sosial, aktivitasnya bahkan hingga ke arsitekturnya. Pada abad ke-18 dan hingga sampai saat ini kampung Pekojan masih ramai dan hidup berdampingan dengan penduduk Pribumi.

\section{Metode Penelitian}

Langkah-langkah yang digunakan dalam penelitian ini yaitu melalui metode sejarah dan menggunakan penelitian deskriptif analisis, Sebagai cara untuk memaparkan kondisi komunitas Arab dan masyarakat Arab di kampung Pekojan, Jakarta pada abad ke-20, maka langkah-langkah penelitiannya sebagai berikut:

\section{a) Heuristik}

Heuristik berasal dari bahasa Yunani yang artinya heuriskein yang artinya "menemukan". Pada tahap ini, kegiatan diarahkan pada penjajakan, pencarian, dan pengumpulan sumber-sumber yang sesuai dengan tema penelitian. Sumber sejarah dibagi menjadi tiga, yaitu tulisan, lisan dan benda. ${ }^{9}$ Heuristik merupakan suatu keterampilan dalam menemukan, menangani dan memperinci atau mengklasifikasi pada sumber-sumber berupa buku, dokumen, arsip, dan gambar-gambar (foto) yang terkait dengan objek penelitian yang akan di kaji, baik itu sumber primer maupun sumber sekunder yang akan menunjang pengerjaan skripsi. Pada tahapan ini, penulis berusaha mencari dan mengimpun sumber-sumber yang dianggap relevan dan kredible dengan bidang kajian atau topik yang akan dibahas.

\section{b) Kritik}

Tahapan kritik ini merupakan tahap penilaian, pengujian atau penyeleksian. Jejak-jejak sejarah tersebut sebagai usaha untuk mendapatkan jejak atau sumber yang benar, yang otentik serta benar-benar mengandung informasi yang relevan dengan cerita sejarah yang akan disusun. Kritik merupakan evaluasi terhadap sumber yang didalamnya mencakup kritik eksternal dan internal terhadap sumber yang akan digunakan. Setelah melakukan kritik ekstern dan kritik intern terhadap sumber yang terkumpul mengenai perkembangan komunitas Arab di Indonesia: Studi kasus perkampungan masyarakat Arab di kampung Pekojan Jakarta Barat pada

${ }^{9}$ Prof. Dr. H Sulasman, Teori Dan Metodologi Penelitian Sejarah (Bandung: Pustaka Setia, 2014), 95. 
Perkembangan Komunitas Arab di Indonesia: Studi Kasus Perkampungan Masyarakat Arab di Pekojan Jakarta Barat Pada Tahun 1950-2018 | Rizal Nasser, Sulasman

tahun 1950-2018, maka sumber tersebut dikelompokan menjadi sumber primer dan sumber sekunder.

\section{c) Interpretasi}

Tahapan berikutnya adalah tahapan interpretasi. Dimana penulis berusaha menafsirkan fakta-fakta sejarah serta menetapkan makna dan keterkaitannya satu sama lain. Karena sejatinya, interpretasi tahapan atau kegiatan menafsirkan fakta-fakta serta menetapkan makna yang salin berhubungan dari fakta-fakta yang telah diperoleh sebelumnya. ${ }^{10}$ Interpretasi atau penafsiran sejarah sering disebut dengan analisis sejarah.

Berkaitan dengan kajian ini, untuk melihat perkembangan masyarakat Arab di Indonesia, bahwa "Rute Perdagangan yang di lakukan orang-orang Arab ke Nusantara melalui Arab Selatan dan Kepualuan Asia Tenggara diterangi oleh para ahli di abad ke tujuh. Gelombang pertama migrasi yang substansial ke Nusantara berlangsung pada sekitar akhir abad ke-18. Hanya laki-laki yang diizinkan untuk berkelana ke luar wilayahnya, dan tidak ada yang perempuan. Mereka kemudian membentuk koloni disejumlah kota-kota di Indonesia, seperti: Jakarta, Cirebon, Semarang, Tegal, Pekalongan, Surabaya, Gresik, Aceh, Palembang, Pontianak, dan masih banyak lainnya". ${ }^{11}$ Dalam hal ini hubungan sosial dan ekonomi juga mempengaruhi, begitu pun menurut G.F. Pijper, beliau berpendapat bahwa di Indonesia terdapat 5 golongan keturunan Arab di yaitu, golongan Saada, golongan Qabaail, golongan Masyaayikh, golongan Da'fa, golongan Abiid, ini membuat orang-orang Arab yang datang ke Indonesia memiliki sistem kastakasta pada stratifikasi sosial yang berusaha mempertahankan dengan gigih pada hubungan sosialnya". ${ }^{12}$

d) Historiografi

Historiografi dalam penulisan sejarah adalah proses menguji dan menganalisis secara kritis terhadap jejak peninggalan pada masa lampau. Rekrontruksi yang imajinatif dari pada masa lampau berdasarkan data yang diperoleh dengan menempuh proses ini. Dalam tahapan ini, penulis

${ }^{10}$ E. Kosim, Metode Sejarah: Asas Dan Proses (Bandung: Universitas Padjadjaran Fakultas Sastra Jurusan Sejarah, 1984), 34.

${ }^{11}$ Ahmad Athoillah, "Pembentukan Identitas Sosial Komunitas Hadhrami Di Batavia Abad XVIII-XX,” Lembaran Sejarah 14, no. 2 (2018): 150-51, https://jurnal.ugm.ac.id/lembaran-sejarah/article/view/45437.

${ }^{12}$ Suratmin \& Didi Kwartanada, A.R. Baswedan Membangun Bangsa Merajut Keindonesiaan (Jakarta: Buku Kompas, 2018), 11. 
Perkembangan Komunitas Arab di Indonesia: Studi Kasus Perkampungan Masyarakat Arab di Pekojan Jakarta Barat Pada Tahun 1950-2018 | Rizal Nasser, Sulasman

menggunakan metode kualitatif yaitu untuk menyelidiki sebuah fenomena sosial yang terjadi pada sebuah masyarakat. Ini menjadi sebuah problematika dalam menjawab pertanyaan-pertanyaan apa, siapa, kapan, mengapa, bagaimana, yang harus dipecahkan oleh penulis dalam sebuah penelitian sejarah.

\section{Pembahasan}

\section{A. Sejarah Masuknya Komunitas Arab di Indonesia}

Secara umum masuknya komunitas Arab di Indonesia melalui hubungan perdagangan yang terdapat di jalur-jalur pesisir pantai, orang-orang Arab yang telah berkembang dan membuat suatu pola terdapat sebuah hubungan timbal balik serta pertukaran budaya antara masyarakat pesisir dengan para pendagang Arab. Maka dari itu, ekspedisi orang-orang Arab dengan berdagang dan menyebarkan Islam dapat diterima dengan mudah oleh penduduk Lokal di Indonesia. ${ }^{13}$ Dalam hal ini kaitannya dengan komunitas, komunitas dapat dicirikan oleh adanya hubungan-hubungan interaksi manusia seara personal yang intensif di antara masyarakat dalam komunitas yang dapat didefiniskan secara jelas. ${ }^{14}$ Orang-orang Arab membentuk komunitas berdagang untuk dapat menyebarkan misi dan visi mereka dalam menyebarkan Islam dan memiliki hubungan sosial di Indonesia.

Orang-orang Arab ini berasal dari Hadramaut, sebuah wilayah di Yaman Selatan. Pada abad ke-10, orang-orang Arab ini sudah melakukan ekspedisi menggunakan kapal menuju Asia Tenggara. Pada abad berikutnya, ekspedisi ini memberikan dampak kepada jumlah mereka yang berangsur-angsur mulai meningkat. Mereka tidak membawa senjata tetapi hanya ingin berdagang dan berniaga ke Nusantara dengan senang hati. ${ }^{15}$ Hingga, abad ke-18 para perantau Arab mulai datang secara massal ke Nusantara. Dengan dibukanya Terusan Suez dibuka pada tahun 1869, telah membawa dampak terhadap meningkatnya populasi orang-orang Arab Hadramaut di Indonesia. Mereka memiliki profesi sebagai pendang perantara, pemilik toko, menembus pasar dan menyediakan barang dan jasa yang berasal dari Eropa serta melakukan peminjaman kegiatan meminjamkan uang. Dalam hal ini, para imigran yang

${ }^{13}$ Ajid Thohir, Studi Kawasan Dunia Islam: Perspektif Etno-Linguistik Dan GeoPolitik (Jakarta: Rajawali, 2011), 395.

${ }^{14}$ Pranoto Sugimin, Lessons Learned:Pembelajaran Rehab Rekon Pasca Gempa Di Sumatra Barat 30 September 2009 (Padang: BNPN, 2011), 108.

${ }^{15}$ Hamka, Dari Pembendaharaan Lama, 3-4. 
Perkembangan Komunitas Arab di Indonesia: Studi Kasus Perkampungan Masyarakat Arab di Pekojan Jakarta Barat Pada Tahun 1950-2018 | Rizal Nasser, Sulasman

datang dan berbaur dengan penduduk setempat memikiki keterkaitan hubungan sosial. Pada awal abad ke-19, terdapat tidak lebih dari 621 orang Arab dan Moor yang tinggal di pulau Jawa, mereka berprofesi menjadi pendagang dan pemuka agama. Sepanjang abad itu, jumlah orang Arab meningkat lagi pada tahun 1900, minoritas Arab di Hindia Belanda meningkat drastis dari 13.000 menjadi 27.000 jiwa. Pada tahun 1920, komunitas Arab di Indonesia mulai meningkat lagi menjadi 45.000 anggota, pada tahun 1930 jumlah mereka meningkat lagi menjadi 71.335 jiwa. ${ }^{16}$

Di zaman Kolonial, komunitas Arab di Hindia Belanda sebagian besar berasal dari Hadramaut yang menjadi salah satu objek perhatian Pemerintahan Kolonial Belanda dan mendorong mereka untuk membuat misi khusus guna mengetahui tingkat pengaruhnya dalam kehidupan muslim di Hindia Belanda. ${ }^{17}$ Tetapi Pemerintahan Belanda melihat pengaruh Islamisasi yang dibawa oleh orang-orang Arab ke Indonesia mengajak untuk masuk Islam. Pada akhirnya, Pemerintahan Kolonial membuat kebijakan yang mempengaruhi intensitas orang-orang Arab di Indonesia teruatama di pualu Jawa. Kebijakan Pemerintahan Kolonial yaitu kebijakan wijkenstelsel, aturan yang menciptakan pemukiman bagi setiap etnisnya untuk tinggal di wilayah tersebut dan kebijakan ini berlaku untuk bagi golongan yang termasuk Vreemde Osterlingan atau Timur Asing. Maka dari itu, orang-orang Arab di tempatkan pada kampung-kampung yang sudah di tetapkan oleh Pemerintahan Belanda. Orang-orang Arab tinggal di kmpugn di kota-kota besar seperti, Batavia, Surabaya, Aceh, Palembang, Yogyakarta, Semarang, Bali dan Lombok.

\section{B. Peran dan Dakwah Komunitas Arab di Indoensia}

Peran komunitas-komunitas Arab sudah sangat menujukkan sebuah keadaaan yang cukup erat dengan kaum Pribumi dalam penyebaran Islam di Indonesia. Mereka menggunakan metode perdagangan sebagai sebuah jembatan untuk berdakwah dan berinteraksi dengan kaum Pribumi. Di dalam agama Islam di jelaskan bahwa sebaik-baiknya komunitas adalah komunitas yang berada di atas kebenaran. ${ }^{18}$ Maka dari itu, sudah sangat penting untuk membangun hubungan komunitas sebagai sebuah interaksi

${ }^{16}$ Huub De Jonge, Mencari Identitas: Orang Arab Hadrami Di Indonesia 19001950 (Jakarta: KPG, 2019), 40.

${ }^{17}$ Handinoto, Komunitas Cina Dan Perkembangan Kota Surabaya (Yogyakarta: Ombak, 2015), xii.

${ }^{18}$ Dkk Zulkifli, Spirit Islam Kaffah (Samarinda: ARIEFFKA MEDIA, 2019), 24. 
Perkembangan Komunitas Arab di Indonesia: Studi Kasus Perkampungan Masyarakat Arab di Pekojan Jakarta Barat Pada Tahun 1950-2018 | Rizal Nasser, Sulasman

antara anggota yang secara langsung dalam intensitas dan frekuensi yang tinggi, saling mengenal, saling menolong dan berkerja sama. ${ }^{19}$

Dalam hal ini, salah satu kreator dari peran Syekh Ahmad Soorkati yang dapat membangun semangat baru dalam kalangan orang-orang Arab di Indonesia. Ketika beliau mulai datang, orang Arab belum terpecah belah menjadi dua, yaitu Ar-Rabithah Alawiyah dan Al-Irsyad. Bahkan yang mendatangkan Syekh itu ke mari adalah dari kalagan yang kemudiannya membentuk Ar-Rabithah Alawiyah. ${ }^{20}$ Selain itu juga, Al-Irsyad juga sebagai organisasi yang cukup terkenal di kalangan orang-orang Arab di Indonesia. Al Irsyad merupakan sebuah organisasi gerakan Islam yang banyak bergerak di bidang pendidikan dan sosial keagamaan. Organisasi ini didirikan pada tahun 1914 oleh para pendagang dan Ulama keturunan Arab, seperti Syekh Soorkati. Al-Irsyad memperoleh pengakuan dari pemerintah Hindia Belanda setahun kemudian, pada tahun 11 Agustus 1915. Pada tahun pertamanya, A1Irsyad mendirikan sarana pendidikan untuk anak-anak Arab, kemudian juga untuk anak pribumi. Selain itu Al-Irsyad juga mendukung pendidikan anak perempuan. Pada siswa yang berprestasi diberikan beasiswa dan kemudian dikirim belajar ke Mesir.

Dalam metode dakwahnya organisasi keturunan Arab seperi Al-Irsyad berhasil menerapkan pembaharuan di bidang pendidikan dengan mengikut sertakan mata pelajaran tauhid, fikih, dan sejarah Islam dalam kurikulumnya. Pelajaran tauhid dimaksudkan untuk pengembangan mental pelajaran fikih untuk perbaikan akhlak dengan pedoman kepada Al-Qur'an dan hadits, dan pelajaran sejarah untuk mengambil pelajaran dari peradabaan Islam. ${ }^{21}$

Begitupun juga, pengaruh dari Jami'atul Khair. Berdirinya Jamiatul Khair pada tahun 1901, membuat sebuah pengaruh besar dalam kemajuan Islam di Indonesia. Jamiatul Khair didirikan oleh dua bersaudara keluarga Shahab, Ali dan Idrus, serta Syekh Said Basandi. Sebagai sebuah organisasi Islam, Jamiatul Khair juga ikut menyebarkan Pan-Islam dari Sayyid Jamaluddin Al-Afghani, Syekh Muhammad Abduh dan Sayid Rasyid Ridha. Umumnya, anggota organisasi ini adalah keturunan Arab sehingga tidak heran jika organisasi ini berkaitan dengan organisasi-organisasi di Timur

${ }^{19}$ Bagja Waluyo, Sosiologi Menyelami Fenomena Sosial Di Masyarakat (Bandung: PT Setia Purna Inves, 2007), 52.

${ }^{20}$ Abdurrahman Al-Mukaffi, Koreksi Tuntas Buku 37 Masalah Populer (Bekasi: Darul Falah, 2018), 261.

${ }^{21}$ Iwan Gayo, Buku Pintar Seri Junior (Lamongan: Grasindo, 1985), 101. 
Perkembangan Komunitas Arab di Indonesia: Studi Kasus Perkampungan Masyarakat Arab di Pekojan Jakarta Barat Pada Tahun 1950-2018 | Rizal Nasser, Sulasman

Tengah. Maka dari itu, pengaruh dakwah komunitas Arab yang ditimbulkan juga cukup berpegaruh besar bagi Islam di Indonesia. Mereka juga mendatangkan guru agama dari negara Arab, salah satunya adalah Syekh Ahmad Syurkati, yang kemudian setelah berkenti dari Jamiatul Khair, mendirikan perguruan Al-Irsyad. Organisasi ini menarik perhatian dari tokoh-tokoh Islam, seperti: K.H. Ahmad Dahlan (Pendiri Muhammadiyah), H.O.S Tjokrominoto (Pendiri Sarekat Islam), dan H. Agus Salim. Pada tahun 1909, Jamiatul Khair mengajukan permohonan untuk diakui sebagai sebuah organisasi. Akhirnya pada 1905 permohonan itu dapat dikabulkan oleh pemerintahan Kolonial Belanda, itu pun dengan syarat tidak boleh membuka cabang di luar Batavia. Meskipun begitu, dengan pengaruhnya yang cukup besar, Jamiatul Khair akhirnya tersebar ke berbagai daerah, sekalipun dengan nama yang lain. ${ }^{22}$ Sekolah-sekolah Jamiatul Khair juga terdapat di dua tempat yang sudah sangat bersinergi dalam penyebaran Islam, yaitu Pekojan, di Jakarta dan satunya lagi di Bogor. Di Jamiatul Khair, Ahmad Soorkati menjadi faktor penting dalam mengembangkan pendidikan sekolah yang bermutu serta berkemajuan intelektual kaum muslimin serta sekolah yang dikelolanya bertambah pesat. Dan juga, membuat perguruan Jamiatul Khair dapat dikenal luas oleh masyarakat, terutama, oleh mereka yang kebetulan keturunan Arab. ${ }^{23}$

\section{Tokoh-tokoh Komunitas Arab di Indonesia}

Pengaruh tokoh-tokoh komunitas Arab dapat mempengaruhi tingkat penyebaran Islam dan hubungan sosial di Indonesia yaitu Sayyid Muhammad bin Abdurrahman bin Shahab, Sayyid Abubakar bin Abdullah Alatas, Sayyid Alwi bin Muhammad Al-Haddad, Sayyid Ali bin Abdurrahman Al-Habsyi, Sayyid Idrus bin Ahmad bin Shahab, Abdurrahman Baswedan, Hoesin Bafagih, Sultan Hamid II dan Habib Usman bin Yahya.

\section{Tokoh-tokoh Komunitas Arab di Pekojan}

Dalam Perkembangan Komunitas Arab di Indonesia telah memberikan kontribusi besar dalam perdagangan, dakwah, pernikahan dan pendidikan. Selain itu, dengan pengaruh kebijakan yang di buat Pemerintahan Belanda untuk membuat aturan setiap etnis mempunyai pemukiman. Akhirnya, 2011), 106.

${ }^{22}$ Kartum Setiawan, Masjid-Masjid Bersejarah Di Jakarta (Jakarta: Erlangga,

${ }^{23}$ Herry dkk Muhammad, Tokoh-Tokoh Islam Yang Berpengaruh Abad Ke-20 (Jakarta: Gema Insani Press, 2006), 3. 
Perkembangan Komunitas Arab di Indonesia: Studi Kasus Perkampungan Masyarakat Arab di Pekojan Jakarta Barat Pada Tahun 1950-2018 | Rizal Nasser, Sulasman

orang-orang Arab di tempatkan di kampung Pekojan. Kampung Pekojan cukup banyak di pulau Jawa, seperti di Surabaya, Semarang, Bogor dan Jakarta. Di kampung Pekojan Jakarta terdapat beberapa tokoh yang berkontribusi besar dalam menjalin hubungan dengan penduduk lokal ataupun berdakwah di wilayah-wilayah Pekojan, yaitu Syekh Abdullah bin Muhammad bin Abubakar Arfan Baraja, Syeikh Fadhel bin Muhammad bin Awad Bafadhol, Sayyid Abubakar bin Ali Shahab, Syeikh Hammud bin Salim bin Abdul Aziz.

\section{Hasil Penelitian}

\section{A. Sejarah dan Perkembangan Perkampungan Masyarakat Arab di Pekojan}

Awal mula Pekojan terdapat imigran-imigran dari India yang menetap di wilayah tersebut. Nama Pekojan berasal dari kata 'Koja' yang merupakan sebuah sebutan yang cukup popoler dikala itu menemui orang-orang India disana. Tetapi karena kebijakan Pemerintahan Kolonial, akhirnya keturunan Arab yang menjadi mayoritas di Pekojan dan menggantikan orang-ornag India yang dulu tinggal di Pekojan. ${ }^{24}$

Kampung Pekojan adalah suatu kampung dengan hubungan sosial diantara pendagang Gujarat dengan masyarakat Indonesia yang memunculkan sebuah perkampungan yang disebut Pekojan. Hingga saat ini, beberapa kota besar di Indonesia terdapat kampung Pekojan. Pekojan yang diartikan sebagai pendagang Gujarat. Sebagian dari pendagang tersebut menikah dengan wanita Indonesia dari putri-putri raja hingga bangsawan. Oleh karena itum banyak dari keluarga raja atau bangsawan yang masuk Islam dan kemudian diikuti oleh rakyatnya.

Pada abad ke-18, Pekojan menjadi salah satu kawasanatau tempat tingga khusus bagi komunitas Arab dari keturunan India maupun keturunan Arab yang beragama Islam. Dalam sistem yang dilakukan Pemerintahan Kolonial Belanda pada saat itu, memisahkan setiap orang berdasarkan suku dan etnis serta agama tertentu dengan membentuk kelompok pada saat itu, selain ingin lebih mudah mengatur suatu kawasan/wilayah dan untuk lebih mudah pula untuk dapat mendata jumlah penduduk baik yang sudah lama menetap ataupun pendatang yang baru dikawasan tersebut, maka dibentuklah

\footnotetext{
24 “No Title," n.d., https://alwishahab.wordpress.com/2009/08/07/kampung-kojadan-komunitas-india/.
} 
Perkembangan Komunitas Arab di Indonesia: Studi Kasus Perkampungan Masyarakat Arab di Pekojan Jakarta Barat Pada Tahun 1950-2018 | Rizal Nasser, Sulasman

kawasan-kawasan tersebut. Salah satunya kampung Pekojan sebagai kampung Arab di Batavia. Arab. Di Pekojan inilah Belanda memberlakukan sistem passen stelsel. Mereka yang tinggal di kawasan Pekojan bila hendak pergih ke daerah harus terlebih dahulu mendapatkan surat jalan dari Kapiten Arab di wilayah Pekojan. ${ }^{25}$

Kampung Arab Pekojan masuk ke dalam bagian dari Distrik Penjagalan. Pada masa pemerintahan Belanda kelurahan Penjagalan berada di bawah Penjaringan Wijk, Onderdistn'ct Penjaringan dan District Batavia yang pada masa itu masih disebut Kampung Penjagalan. Pada masa pendudukan Jepang, Kampung Penjagalan masuk Penjaringan Son, Kawedanan Jakarta Kota. Setelah Kemerdekaan sampai tahun 1967 Kampung Penjagalan masuk wilayah Kelurahan Penjagalan. Kec. Penjaringan, Jakarta Utara. Tetapi, pemekaran kota, pada tahun 1967, wilayah Kelurahan Penjagalan dipecah menjad 2, yaitu sebagian masuk kedalam wilayah Kelurahan Pekojan, Kec. Tambora, dan Sebagian masuk wilayah Penjagalan Utara, Penjaringan, Jakarta Utara. ${ }^{26}$

Selama ini Arab berbagi tempat dengan Muslim asing lainnya. Di Batavia, tempat tinggal orang-orang Arab ini disebut Pekojan, setelah Koja atau Moor yang melebihi jumlah minoritas Muslim lainnya sampai pada awal abad ke-19. Namun, setelah 1880, jumlah imigran Arab secara bertahap meningkat dan Pekojan akhirnya menjadi seperempat Arab. Pertumbuhan konstan komunitas Arab di Hindia terlihat dari pendirian tempat baru, penciptaan pangkat Jurumudi (wijkmeester), dan pengangkatan dan gaji pejabat seperempat. Pada tahun 1873, Hindia Belanda memiliki 35 perempat untuk "Orang Asing Orang Asing Lain", di antaranya orang Arab menjadi kelompok terbesar, 23 di Jawa dan 12 di Kepulauan Quter. Di hampir semua kota, perdagangan menjadi cukup penting bagi kawasan yang didirikan oleh orang-orang Arab. ${ }^{27}$ Dan hingga abad ke-20, sebagian besar orang-orang Arab di Jakarta tinggal di kampung Pekojan dan seperempat orang-orang 2006), 120.

${ }^{25}$ Alwi Shahab, Maria Van Engels: Menantu Habib Kwitang (Jakarta: Republika,

${ }^{26}$ Abdul Jamil Wahab, Harmoni Di Negara Seribu Agama (Jakarta: PT Elex Media Komputindo, 2015), 60.

${ }^{27}$ William G. Clarence-Smith Ulrike Freitag, Hadrami Traders Scholars, and Statesmen In the Indian Ocean 1750s-1950s (Leiden: Koninklijke Brill, 1997), 99. 
Perkembangan Komunitas Arab di Indonesia: Studi Kasus Perkampungan Masyarakat Arab di Pekojan Jakarta Barat Pada Tahun 1950-2018 | Rizal Nasser, Sulasman

Moor, antara Ammanusgracht (sekarang jalan Bandengan Selatan) dan Bacherachtsgracht (sekarang jalan Pekojan). ${ }^{28}$

\section{B. Aktivitas Perdagangan dan Keagamaan Masyarakat Arab di Pekojan}

Perdagangan menjadi salah satu upaya untuk membangun perekonomian masyarakat yang cendrung dalam kemerosotan. Menurut pendapat Adam Smith terkait perdagangan, bahwa masyarakat terbelakang ditandai dengan mata pencarian berburu, sedangkan masyarakat di daerah maju ditandai dengan mata pencarian berdagang. Pada periode masa-masa awal perdagangan dikuasai oleh masyarakat Arab yang disebut dengan masyarakat pemimpin. Keberhasilan yang dilakukan oleh pendagang-pendagang Arab terhadap negara-negara perdagangan ialah menciptakan perdagangan dengan metode keramahan dan kemuliaan hati. Dengan keberhasilan tersebut masyarakat Arab dapat diterima dengan baik secara suka rela oleh kalangan pendagang di seluruh dunia. Tepatnya Smith menulis: "Ketika mereka memasuki kota, mereka mengundang orang-orang dijalan, baik kaya maupun yang miskin untuk makan bersama dengan duduk bersila. Mereka memulai makan dengan mengucapkan bismillah dan mengakhirinya dengan ucapan hamdallah". ${ }^{29}$

Adapun dilihat dari aktivitas Perdagangan yang dilakukan oleh orangorang yang berketurunan Arab, cukup memiliki kontribusi besar dalam menjalin hubungan erat dengan pendagang-pendagang Cina, Betawi, Jawa, Batak dan lainnya. Dalam hal ini cukup banyak toko-toko milik orang Arab di Batavia, sekitar tahun 1920. Barang yang mereka jual seperti terlihat di Tanah Abang seperti minyak wangi, madu, korma dan ma'jun. di depan sekali tampak hoga yang kala itu banyak juga terdapat di kediaman etnis Arab. Para pendagang ini menggunakan jubah dan sorban serta peci putih. Orang Arab banyak berdatangan ke Nusantara terutama pada abad ke-19. Mereka diharuskan untuk tinggal di perkampungan Arab, Pekojan dan Krukut, karena Belanda juga mengenakan passen stelsel terhadap mereka. Bila mereka ingin berpergian ke daerah lain seperti Jatinegara, mereka diharuskan untuk menyiapkan surat jalan. Kedatangan para imigran Arab

${ }^{28}$ Peter J.M. Nas Kees Grijns, Jakarta-Batavia Sosial-Culural Essay (Leiden: KITLV, 2000), 134-40.

${ }^{29}$ Bustanul Karim, Prinsip Pembangunan Ekonomi Umat: Upaya Menggali Petunjuk Al-Qur'an Dalam Mewujudkan Kesejahteraan (Yogyakarta: IKAPI, 2018), 76. 
Perkembangan Komunitas Arab di Indonesia: Studi Kasus Perkampungan Masyarakat Arab di Pekojan Jakarta Barat Pada Tahun 1950-2018 | Rizal Nasser, Sulasman

dari Hadramaut ke Nusantara ini, selain untuk berdagang, mereka juga melakukan kegiatan keagamaan. ${ }^{30}$

Dalam kegiatan keagamaan, terdapat masjid yang cukup terkenal disana yaitu masjid An-Nawier. Pengaruh dari Masjid An-Nawier yang namanya berarti cahaya ada di Jalan Pekojan, Jakarta Barat, dan ditugaskan oleh seorang keturunan Nabi Muhammad melalui Fatimah putrinya yaitu Abdullah bin Hussein Alaydrus. Sayyid Abdullah membangun masjid AnNawier pada tahun 1760. Masjid ini juga menjadi salah satu pusat kampung Arab Pekojan dari segi keagamaan. Masjid yang jauh dari jalan besar dengan keramaiannya menjadi ketertarikan tersendiri terhadap masyarakat Arab Pekojan maupun penduduk lokal disana untuk beribadah di masjid tersebut. Dengan kata lain aktivitas keagamaan menjadikan unsur Islamiyah yang dipraktikkan oleh rakyat masyarakat Pekojan. Maka dari itu, manfaat dari masjid tersebut bagi masyarakat di Pekojan maupun di luar Pekojan secara langsung juga ikut sdalam aktivitas keutamaan shalat lima waktu serta shalat jum'at dan doa khusus pada waktu akhir yang pada umumnya diajarkan didalam agama Islam serta kegiatan keagamaan juga disampaikan oleh ulama-ulama yang ada di Pekojan maupun dari luar Pekojan dengan memberikan pidato dan khutbahnya. ${ }^{31}$

Pada abad ke-20 migrasi orang-orang Arab dari Hadramaut ke Nusantara mulai cukup banyak dan menempati beberapa daerah-daerah yang sudah di tetapkan oleh Pemerintahan Kolonial Belanda. Tidak heran jika di Pekojan, Krukut, Tanah Abang, Kwitang dan baru-baru ini wilayah Condet menjadi sentral perekonomian orang-orang berketurunan Arab yang senantiasa menjajakan dagangan mereka di depan toko-toko mereka. Kesukaaan mereka adalah makan daging kambing, juga memasok kebutuhan makanan seperti daging kambing.

\section{Tantangan dan Hubungan Sosial Komunitas Arab dengan Masyarakat Pribumi di Pekojan}

Tantangan yang dihadapkan bagi komuntasi Arab dengan masyarakat Pribumi tidak terlalu berat. Bahkan orang-orang Arab dapat diterima dan dihormati oleh penduduk Lokal. Namun, tatangan itu hadir pada masa Kolonial dan dari perselisiha intern dari komunitas Arabnya sendiri. Dari

\footnotetext{
${ }^{30}$ Alwi Shahab, Betawi Queen of The East (Jakarta: Penerbit Republik, 2002), 66.

${ }^{31}$ Terry Collins Derek Bacon, Culture Shock Jakarta: Survival Guide to Customs and Etiquette Jakarta, 2007, 75.
} 
Perkembangan Komunitas Arab di Indonesia: Studi Kasus Perkampungan Masyarakat Arab di Pekojan Jakarta Barat Pada Tahun 1950-2018 | Rizal Nasser, Sulasman

aspek Dari aspek Perdagangan, perdagangan menghadirkan tantangan tersendiri yang dirasakan oleh para pendagang Arab yang hadir di wilayah Batavia yang berpusat di Pekojan. Bahwa kehadiran orang-orang Arab cukup diterima oleh orang-orang Pribumi karena dari mereka memiliki sifat yang ulet, rajin dan memiliki interaksi sosial dalam bernegosiasi perdagangan. Tetapi terdapat beberapa pembatasan yang juga diberlakukan oleh pemerintahan Kolonial Belanda pada sistem waktu, sistem pas, dan hukum imigrasi. kebijakan-kebijakan ini, yang secara resmi dinyatakan berlaku untuk semua komunitas imigran secara setara, diterapkan secara selektif. Salah satu kebijakan keras semacam itu adalah membatasi daerah-daerah dimana orang Arab dapat tinggal, seperti Pekojan, Batavia. Van Den Breg mengamati bahwa sistem ini menyebabkan masalah bagi orang-orang Arab karena komunitas mereka yang sudah ada menjadi sangat banyak. Selain itu juga, mereka harus mengajukan permohonan izin perjalanan untuk berpergian, baik melalui darat maupun laut, di luar kawasan. Semua penerapan semacam itu diajukan ke proses persetujuan yang sangat luas, yang dapat menyulitkan pedagang untuk bepergian dalam menangani masalah bisnis. ${ }^{32}$

Dari aspek Dakwah, dakwah Islam sudah dilakukan sebelum zaman Rasulullah Saw. Tetapi Rasulullah Saw-lah bersama para sahabatnya menjadi puncak untuk menyebarkan agama Islam ke wilayah-wilayah Jazirah Arab. Islam yang dibawa Rasulullah Saw adalah agama Islam yang menjalakan segala perintah Allah dan menjauhi larangannya serta berlandaskan pada Al-Qur'an dan Hadist sebagai dasar utama sandaran umat Islam. Terutama agama Islam yang mengajarkan untuk menciptakan perdamaian dimuka bumi dan bertoleransi antar sesama manusianya. Tugasnya adalah untuk mengajak manusia pada ajaran yang diridai Allah dengan metode berdakwah dan ini bukanlah hanya tugas para nabi dan rasul semata. Melainkan tugas tersebut merupakan tugas seluruh kaum muslimin untuk mengajak manusianya pada jalan yang dicintai Allah Swt. Perlu di ketahui, Islam dapat diterima baik oleh penduduk Lokal. Bahkan penduduk Lokal sangat mudah berosialisasi untuk mengucapkan dua kalimat Syahadat dan akhirnya masuk agama Islam demi ingin mengikuti tuntunan serta syariat yang berlandaskan Al-Qur'an dan Hadist.

${ }^{32}$ Salim Kayadibi, Ottoman Conetions To The Malay World (Malaysia: The Other Press, 2011), 11. 
Perkembangan Komunitas Arab di Indonesia: Studi Kasus Perkampungan Masyarakat Arab di Pekojan Jakarta Barat Pada Tahun 1950-2018 | Rizal Nasser, Sulasman

Habib Ahmad bin Alwi Assegaf berpendapat bahwa "Orang-orang Pribumi disini ketika kedatangan orang-orang Arab kewilayah ini, mereka merasa lebih di hormati. Mereka diajak bersatu dan maka diadakan halal bihalal dan diadakan juga khataman Qur'an. Mereka diajak dengan ikut tadarus Qur'an sehingga mereka merasa di hargai dan ikut halal bihalal dapat konsumsi yang bagus. Dalam artian, mereka dapat makanan kebuli makanan, teman-teman dan dapat ceramah juga. Rohani dan jasmani mereka bergembira dan senang. Serta di Pekojan juga mereka berdakwah ke wilayah kulon yaitu Serang. Mereka membangun persantren-pesantren tersebut dengan belajar agama di Pekojan. Mereka juga mengetahui bahwa di Pekojan juga banyak guru-guru besar". ${ }^{33}$ Untuk saat ini, dakwah Islam yang dilakukan di kampung Pekojan, masih terus syiarkan demi terciptanya kebersaman antar umat Islam di Pekojan. Dakwah para Habib dan Ustadz yang senantiasa menjadi pemberi pemahaman tentang agama Islam bagi masyarakat di Pekojan.

Aspek perkawinan, terdapat perbedaan dikalangan orang-orang Arab yang terjadi karena golongan Sayyid dan non-Sayyid. Ini dapat mempengaruhi perkembangan sosial masyarakat Indonesia sendiri serta mempengaruhi identitas keturunana Arab. Dikarekan pelapisan sosial yang tajam seperti di Hadramaut tidak mungkin lagi dikembangkan di Indonesia. Pergerakan dan kebangkitan nasionalisme Indonesia mempengaruhi pula sikap sosial mereka, sehingga mendorong timbulnya semacam gerakan mdernisme Arab Indonesia. Salah satu hasilya adalah penyempitan golongan Keturunan Arab menjadi dua yaitu Al-Alwe (Sayyid atau biasa di sebut tuan) dan golongan Al-Irsyad (yang menyebut diri mereka Irsyadin). Dari kedua golongan ini masuh tetap mencerminkan dari pengelompokkan berdasarkan keturunan, dimana golongan Sayyid mengangap bahwa mereka merasa sebagai keturunan Nabi dan yang Al-Irsyad menganggap diri mereka sebagai keturunan Arab yang lebih terbuka dan moderat. Dalam kehidupan seharihari diantara hubungan dari kedua golongan ini tidak dapat dikatakan harmonis, karena adanya sikap mengagungkan kemurnian keturunan yang cukup ketat. Dapat diduga, bahwa perkawinan antar kedua golongan ini tidak mudah terjadi. Karena menurut adat orang-orang Arab di Indonesia perkawinan yang ideal terjadi antara seorang laki-laki dengan gadis anak

${ }^{33}$ Wawancara Habib Ahmad bin Alwi Assegaf di Pekojan, Jakarta Barat pada tanggal 26 Januari 2020 jam 18:23 
Perkembangan Komunitas Arab di Indonesia: Studi Kasus Perkampungan Masyarakat Arab di Pekojan Jakarta Barat Pada Tahun 1950-2018 | Rizal Nasser, Sulasman

saudara perempuan ayah, sehingga cenderung untuk bersifat endogami klen (menikah dalam lingkungan keluarga sendiri). Akan tetapi sebagian orang Arab sekarang lebih suka mengembangkan hubungan kekerabatan melalui perkawinan keluarga klen, yang sebenarnya berarti mempererat hubungan sesama keturunan Arab. ${ }^{34}$

Namun, menurut Nabiel A. Kariem Hayaze bahwa "orang-orang Arab datang ke Indonesia tidak membawa Istri. Mereka yang datang ke kampung Pekojan, Jakarta menikah dengan perempuan-perempuan Betawi asli. Jadi, mereka sudah di anggap sebagai bagian dari masyarakat Betawi. Mereka menjalin hubungan yang begitu dekat antara Betawi dan Arab", ${ }^{35}$

Salah satunya terjadi di kampung Pekojan, Jakarta. Diantara beberapa golongan Sayyid di Pekojan masih menekankan anaknya untuk menikah dengan keturunan Arab yang bergolongan Sayyid. Karena mereka tidak ingin nasab atau marga mereka hilang begitu saja di Indoensia. Terutama untuk menjaga agar keturunan mereka tidak tercampur dengan golongan yang nonSayyid maupun yang penduduk Pribumi. Golongan non-Sayyid pun yang serta merta menerima dengan segala aspek keturunan, telah mampu menciptakan hubungan yang baik dalam status pernikahan mereka dengan golongan Sayyid maupun penduduk Pribumi. Begitu pun hingga saat ini sebagian dari orang-orang Arab ini tidak hanya mengembangkan hubungan kekerabatan melalui perkawinan keluarga klen, tetapi diantara mereka juga menjalin hubungan pernikahan dengan orang-orang Pribumi. Karena dari diri mereka merasa bahwa asimilasi yang mereka buat meyakinkan mereka untuk memiliki hubungan pernikahan oleh penduduk Pribumi. Maka kepercayaan mereka mendorong mereka untuk menciptakan kekeluargaan dengan masyarakat Pribumi. Walaupun sebagian pandangan orang-orang Arab masih bertumpu pada penikahan sesama keturunan Arab.

Aspek Pendidikan, orang-orang Arab mulai membangun bersamabersama dalam aspek perdagangan, dakwah, perkawinan dan terutama Pendidikan. Orang-orang Arab ini mengajarkan pendidikan Islam sesuai ajaran Rasulullah Saw. Dengan begitu, Al-Qur'an dan Hadist menjadi sandaran mereka sebagai media pengajarannya. Selain itu, orang-orang Arab

${ }^{34}$ Zulyani Hidayah, Ensiklopedi Suku Bangsa Di Indonesia (Jakarta: Pusataka Obor, 2015), 10.

${ }^{35}$ Wawancara Bapa Nabiel A. Kariem Hayaze pada tanggal 8 Juni 2020 jam 14:00 
Perkembangan Komunitas Arab di Indonesia: Studi Kasus Perkampungan Masyarakat Arab di Pekojan Jakarta Barat Pada Tahun 1950-2018 | Rizal Nasser, Sulasman

ini mengajarkan kitab-kitab kepada masyarakat Pribumi dan keturunan Arab lainnya tentang moral, etika dan budi perkerti yang baik.

Di Pekojan, pendidikan yang di bangun oleh orang-orang Arab di cukup mempengaruhi pada penduduk di wilayah Pekojan. Mereka memakmurkan masjid dan mengajarkan pendidikan Islam seperti di Masjid Az-Zawiyah. Masjid Az-Zawiyah adalah salah satu masjid yang di bangun diwilayah Pekojan pada abad tahun 1812 oleh Habib Ahmad bin Hamzah Alatas. Beliau berasal dari Tarim, Hadramaut berdakwah di Indonesia hingga ke Pekojan. Habib Ahmad merupakan seorang guru dari Habib Abdullah bin Muhsin Alatas, seorang ulama yang berdakwah di daerah Bogor. Sejak masjid ini dibangun, tidak saja merupakan bangunan tempat ibadah tetapi juga penyelenggaraan pendidikan Islam di Pekojan.

\section{Simpulan}

Berdasarkan pembahasan di atas maka dapat disumpulkan sebagai berikut:

Kampung Pekojan pertama kali di bangun oleh pemerintah Hindia Belanda terjadi di Batavia atau sekarang biasa disebut Jakarta. Sejak masa Kolonial, kampung tersebut sudah menjadi kampung yang menunjukan siklus perdagangan yang dilakukan oleh orang-orang Arab dengan penduduk Pribumi maupun dengan pendagang dari negara lainnya. Orang-orang Arab ini berdagang dengan cara membuka toko-toko Arab di sekitaran wilayah Pekojan. Mereka memiliki sifat yang cukup khas dari pola dagang yang dilakukannya seperti: sifat ulet, rajin, jujur, dermawan, tekun dan mereka juga orang yang dipercayai sebagai pendagang yang berkomitmen oleh para pendagang lainnya. Tetapi dari sifat tersebut, para saudagar Arab dapat di terima dengan baik oleh para pendagang dari Barat, dari Cina maupun penduduk Pribumi. Sementara itu, dari sikap pendagang-pendagang Arab yang diterima baik oleh kelompok etnis lainnya terutama dengan penduduk Pribumi, disaat itu juga mereka membangun komunitas-komunitas Arab dari aspek dakwah dengan misi menyebarkan Islam, perkawinan dengan penduduk Pribumi bahkan membentuk organisasi-organisasi pendidikan yang berbasis Islam.

Sementara itu, hingga abad ke-20 orang-orang Arab sudah menetap dan berasimilasi dengan penduduk Pribumi. Mereka sudah meyakinkan bahwa Indonesia adalah tanah air orang-orang Arab. Dengan begitu, mereka 
Perkembangan Komunitas Arab di Indonesia: Studi Kasus Perkampungan Masyarakat Arab di Pekojan Jakarta Barat Pada Tahun 1950-2018 | Rizal Nasser, Sulasman

mempuk persaudaraan dan menumbuhkan rasa Nasionalisme terhadap Indonesia dengan menjalin hubungan persaudaraan dengan masyarakat Indonesia. Dari rasa Nasionalisme dan menjalin hubungan persaudaraan membuat mereka tidak ada bedanya dengan penduduk Indonesia, hanya saja membedakan dengan bentuk mukanya.

\section{Daftar Sumber}

Agadri, Hamid. Islam Dan Keturunan Arab Dalam Pemberontakan Melawan Belanda. Bandung: Mizan, 1996.

Al-Mukaffi, Abdurrahman. Koreksi Tuntas Buku 37 Masalah Populer. Bekasi: Darul Falah, 2018.

Athoillah, Ahmad. "Pembentukan Identitas Sosial Komunitas Hadhrami Di Batavia Abad XVIII-XX.” Lembaran Sejarah 14, no. 2 (2018): 150-70. https://jurnal.ugm.ac.id/lembaran-sejarah/article/view/45437.

Berg, Lodewijk Willem Christiaan van den. Hadramaut Dan Koloni Arab Di Nusantara. Jakarta: INIS, 1989.

Breg, Van Den. Orang Arab Di Nusantara. Depok: Komunitas Bambu, 2010.

Derek Bacon, Terry Collins. Culture Shock Jakarta: Survival Guide to Customs and Etiquette Jakarta, 2007.

F.Jacobsen, Frode. Hadrami Arab In Present-Day Indonesia. London: Routledge, 2009.

Gayo, Iwan. Buku Pintar Seri Junior. Lamongan: Grasindo, 1985.

Grijns, Peter J.M. Nas Kees. Jakarta-Batavia Sosial-Culural Essay. Leiden: KITLV, 2000.

Hamka. Dari Pembendaharaan Lama. Jakarta: Gena Insani, 2017.

Handinoto. Komunitas Cina Dan Perkembangan Kota Surabaya. Yogyakarta: Ombak, 2015.

Hidayah, Zulyani. Ensiklopedi Suku Bangsa Di Indonesia. Jakarta: Pusataka Obor, 2015.

Jonge, Huub De. Mencari Identitas: Orang Arab Hadrami Di Indonesia 1900-1950. Jakarta: KPG, 2019.

Karim, Bustanul. Prinsip Pembangunan Ekonomi Umat: Upaya Menggali Petunjuk Al-Qur'an Dalam Mewujudkan Kesejahteraan. Yogyakarta: IKAPI, 2018. 
Perkembangan Komunitas Arab di Indonesia: Studi Kasus Perkampungan Masyarakat Arab di Pekojan Jakarta Barat Pada Tahun 1950-2018 | Rizal Nasser, Sulasman

Kayadibi, Salim. Ottoman Conetions To The Malay World. Malaysia: The Other Press, 2011.

Koentjaraningrat. Penghantar Ilmu Antroologi. Jakarta: Aksara Baru, 1980.

Kosim, E. Metode Sejarah: Asas Dan Proses. Bandung: Universitas Padjadjaran Fakultas Sastra Jurusan Sejarah, 1984.

Kwartanada, Suratmin \& Didi. A.R. Baswedan Membangun Bangsa Merajut Keindonesiaan. Jakarta: Buku Kompas, 2018.

Muhammad, Herry dkk. Tokoh-Tokoh Islam Yang Berpengaruh Abad Ke-20. Jakarta: Gema Insani Press, 2006.

"No Title," n.d. https://alwishahab.wordpress.com/2009/08/07/kampungkoja-dan-komunitas-india/.

Notosusanto, Marwati Djoened Poesponegoro dan Nugroho. Sejarah Nasional Indonesia IV. Jakarta: Balai Pustaka, 1993.

R.Nugroho dan G. Sumodiningrat. Membangun Indonesia Emas. Jakarta: Elex Media Komputindo, 2005.

Setiawan, Kartum. Masjid-Masjid Bersejarah Di Jakarta. Jakarta: Erlangga, 2011.

Shahab, Alwi. Betawi Queen of The East. Jakarta: Penerbit Republik, 2002. . Maria Van Engels: Menantu Habib Kwitang. Jakarta: Republika, 2006.

Sugimin, Pranoto. Lessons Learned:Pembelajaran Rehab Rekon Pasca Gempa Di Sumatra Barat 30 September 2009. Padang: BNPN, 2011.

Sulasman, Prof. Dr. H. Teori Dan Metodologi Penelitian Sejarah. Bandung: Pustaka Setia, 2014.

Thohir, Ajid. Studi Kawasan Dunia Islam: Perspektif Etno-Linguistik Dan Geo-Politik. Jakarta: Rajawali, 2011.

Ulrike Freitag, William G. Clarence-Smith. Hadrami Traders Scholars, and Statesmen In the Indian Ocean 1750s-1950s. Leiden: Koninklijke Brill, 1997.

Wahab, Abdul Jamil. Harmoni Di Negara Seribu Agama. Jakarta: PT Elex Media Komputindo, 2015.

Waluyo, Bagja. Sosiologi Menyelami Fenomena Sosial Di Masyarakat. Bandung: PT Setia Purna Inves, 2007.

Zulkifli, Dkk. Spirit Islam Kaffah. Samarinda: ARIEFFKA MEDIA, 2019. 
Perkembangan Komunitas Arab di Indonesia: Studi Kasus Perkampungan Masyarakat Arab di Pekojan Jakarta Barat Pada Tahun 1950-2018 | Rizal Nasser, Sulasman 